ISSN 0122-5383

\title{
ACUTE TOXICITY OF DRILLING MUDS ON LITOPENAEUS VANNAMEI (BOONE, 1931) POSTLARVAE
}

\section{TOXICIDAD AGUDA DE LODOS DE PERFORACIÓN EN POSTLARVAS DE LITOPENAEUS VANNAMEI (BOONE, 1931)}

Guillermo-José Contreras-León ${ }^{1 *}$, Simón-Andrés Rodríguez-Satizábal' ${ }^{1}$, Claudia-Marcela Castellanos-Romero¹, Andrés Franco-Herrera ${ }^{1}$ and Marlon Serrano-Gómez ${ }^{2}$

'Faculty of Science and Engineering, Marine Biology Program, Universidad de Bogotá Jorge Tadeo Lozano, El Rodadero, Santa Marta, Colombia

2 Ecopetrol S.A. - Instituto Colombiano del Petróleo (ICP), A.A. 4185 Bucaramanga, Santander, Colombia

e-mail: gcontreras777@yahoo.com

(Received: May 23, 2013; Accepted: Dec. 20, 2013)

\begin{abstract}
cute toxicity of six drilling muds (water based and synthetic based) was evaluated using Litopenaeus vannamei postlarvae to establish the $96 \mathrm{~h}$ median lethal concentration $\left(\mathrm{LC}_{50}\right)$. The

1 Suspended Particulate Phase (SPP) of each drilling mud was used as test material. Each mud SPP was evaluated using five test concentrations, and four replicates of each were used including the control. LC $_{50}$ values obtained ranged from 4224 ppm to 26635 ppm for Water Based Mud (WBM) and from 40781 ppm to 308248 ppm for Synthetic Based Mud (SBM). The test protocol for acute toxicity for this species was validated through a control chart with the reference toxicant potassium dichromate. Litopenaeus vannamei clearly showed the required conditions to be used in acute toxicity tests. This research is pioneer in Colombia to determine the effects of drilling muds using a local marine organism.
\end{abstract}

Keywords: Drilling muds, Toxicity, Marine organisms, Environmental impact, Offshore.

How to cite: Contreras-León, G. J., Rodríguez-Satizábal, S. A., Castellanos-Romero, C. M., Franco-Herrera, A. \& Serrano-Gómez, M. (2013). Acute toxicity of drilling muds on Litopenaeus vannamei (Boone, 1931) postlarvae. CT\&F - Ciencia, Tecnología y Futuro, 5(3), 127-138.

*To whom correspondence should be addressed 


\section{RESUMEN}

a toxicidad aguda de seis lodos de perforación (base agua y base sintético) fue evaluada utilizando
postlarvas de Litopenaeus vannamei con la finalidad de establecer la concentración letal media a
$96 \mathrm{~h}\left(\mathrm{CL}_{50}\right)$. La Fase Suspendida Particulada (FSP) de cada lodo fue usada como material de prueba.
Cada FSP de los lodos fue evaluada usando cinco concentraciones de prueba con cuatro réplicas de cada
una, incluido el control. Los valores de $\mathrm{CL}_{50}$ obtenidos de la FSP de los Lodos Base Agua (LBA) se encontra-
ron entre $4224 \mathrm{ppm}$ y $26635 \mathrm{ppm}$ y entre $40781 \mathrm{ppm}$ y 308248 ppm para los Lodos Base Sintética (LBS).
El protocolo de ensayo para toxicidad aguda con esta especie se validó mediante una carta control con el
tóxico de referencia (dicromato de potasio). Litopenaeus vannamei mostró tener las condiciones requeridas
para ser usado en pruebas de toxicidad aguda. Este trabajo es pionero en Colombia para evaluar los efectos
de los lodos de perforación con un organismo marino local.

Palabras clave: Lodos de perforación, Toxicidad, Organismos marinos, Impacto ambiental, Costa afuera.

\section{RESUMO}

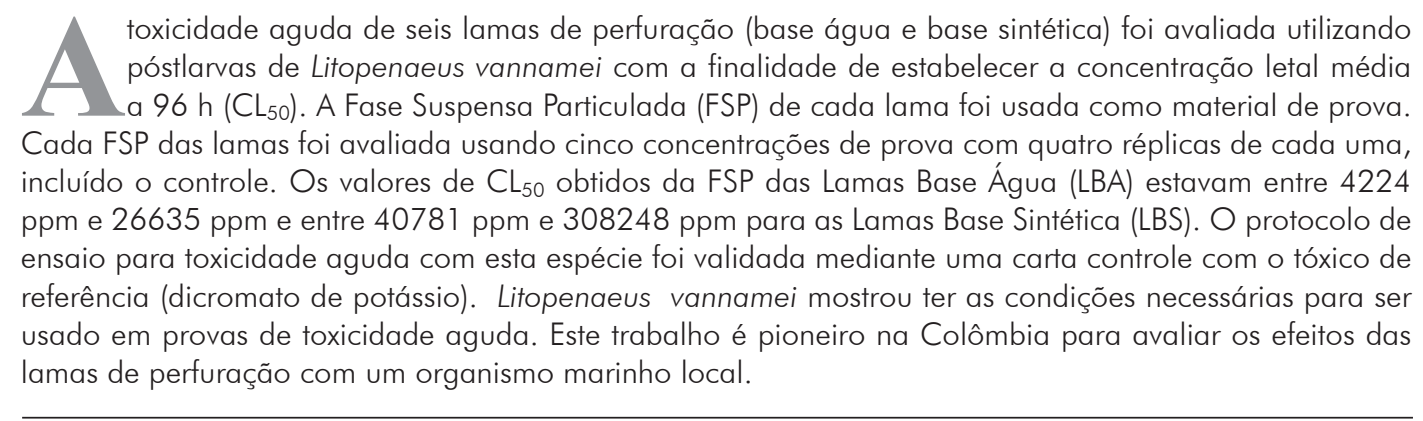

Palavras-chave: Lamas de perfuração, Toxicidade, Organismos marinhos, Impacto ambiental, Offshore. 


\section{INTRODUCTION}

Exploration of offshore oil and gas is conducted on a worldwide scale and long term developments can cause physical, chemical and biological alteration in marine environments (Neff, 2005). Well drilling is one of the main activities in different phases of hydrocarbon development. Drilling muds used for drilling are mixtures of natural and synthetic compounds that have different functions such as: cool down and lubricate the drilling string and drilling bits, remove cuts from downhole carrying them to the surface and control pressure problems, among others (Fink, 2011). Three types of drilling muds are used, including Water Based Muds (WBM), which continuous or liquid phase is seawater and two types of non-aqueous muds: Oil Based Mud (OBM) and Synthetic Based Muds (SBM). The WBM are more commonly used in the main areas of offshore oil drilling while OBM is no longer used. During drilling activities, muds and cuttings wastes are generated in considerably amounts and their discharge to the ocean is regulated in many countries, mainly due to concerns on the impacts of solids and toxicity of chemical waste in the water column and benthic ecosystems (Neff, 2008).

The assessment of potential impacts to the marine environment is established through acute toxicity, chronic toxicity and bioaccumulation studies (Melton et al., 2000). A wide variety of organisms have been used to evaluate the acute toxicity of drilling muds. In 1983, the National Research Council (NRC) published a report making an assessment of fates and effects of drilling fluids in marine environment and an evaluation was performed -based on secondary information- of 400 assays with 72 WBM conducting on 62 different marine species from seas of the United States of America (USA). The organisms used included fish, crustaceans, molluscs, polychaeta and echinoderms. Crustaceans, specifically copepods, mysids and shrimp in early life stages, demonstrated to be more sensible than other taxa (NRC, 1983). In 1985, the Environmental Protection Agency of the United States (EPA) determined the use of Mysidopsis bahia (Crustacea) as the organism to carry out acute toxicity tests, establishing a $96 \mathrm{~h} \mathrm{LC}_{50}$ value of $>30000 \mathrm{ppm}$ of the SPP to allow discharges of WBM into marine waters of the United States of America (USA) (EPA, 1993; Code of Federal Regulations, 2012). In Brazil, Mysidopsis juniae is used for testing and the acute toxicity value required for mud discharges is similar to the one in the USA. (Cupello, Marroquin, Franca \& Rabke, 2010).

The objective of this study was to validate a protocol for the evaluation of acute toxicity using Litopenaeus vannamei and to test with it six drilling muds (3 WBM and 3 SBM).

The white shrimp (L. vannamei), is distributed in the Pacific coast of America, from Southern México to Northern Perú (Luvesuto, Domingues de Freitas \& Galleti, 2007; Rivera-Velásquez, Salgado-Ugarte, Soto \& Naranjo, 2010). It is an epibenthic species that, as an adult, lives and reproduces in ocean waters, while postlarvae migrates to the coast spending juvenile and pre-adult phase in estuaries (Campos, Navas, Bermúdez \& Cruz, 2005; Valles-Jiménez, Cruz \& Pérez-Enríquez, 2005). It is also an important catch group and represents a high percentage of industrial and handcrafted fishing in the Colombian Pacific coast (SIPA, 2009). L. vannamei have been introduced successfully in the colombian Caribean coast in acuculture facilities with comercial propourses. Juvenile organisms or postlarvae of these species have been used to evaluate pesticides, oil dispersants and mainly toxicity of metals; characteristics of assays are shown in Table 1. Due to the availability of organisms from hatchery production under controlled conditions, it becomes an important test species for Colombia. Based on existing protocols from EPA (2002), the Asociacao Brasileira de Normas Técnicas - ABNT (2005) and related literature on drilling muds and acute toxicity tests with marine organisms, a protocol for evaluation of acute toxicity of drilling muds on L. vannamei was generated.

\section{MATERIALS AND METHODS}

\section{Sea Water}

Natural seawater was used for organism maintenance, muds preparation and test dilutions. Water was obtained from Gaira Bay (Santa Marta, Colombia), prefiltered through four terraces of gravel, a series of 20 and $1 \mu$ filters, activated charcoal and finally sterilized using UV light. 
Table 1. Conditions for acute tests at $96 \mathrm{~h}$ on L. vannamei.

\begin{tabular}{|c|c|c|c|c|c|c|c|c|c|c|}
\hline 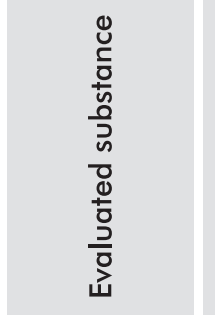 & 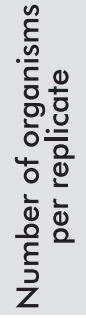 & $\begin{array}{l}0 \\
\frac{0}{0} \\
\frac{0}{n} \\
\frac{0}{0} \\
\frac{1}{0}\end{array}$ & 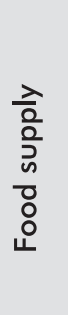 & $\frac{\frac{5}{\frac{0}{7}}}{\frac{0}{0}}$ & 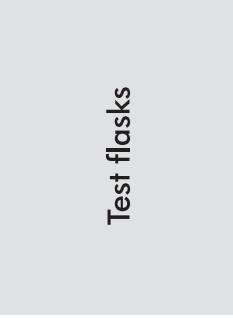 & 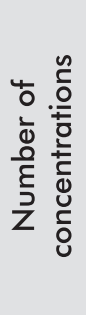 & 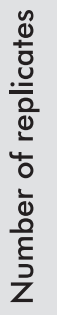 & 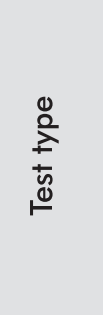 & 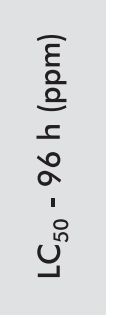 & $\frac{\grave{2}}{\frac{c}{5}}$ \\
\hline $\begin{array}{c}\text { Oil } \\
\text { dispersant }\end{array}$ & 5 & $\begin{array}{l}\text { Postlarvae } \\
\quad(P L 5)\end{array}$ & Yes & - & $\begin{array}{l}\text { Glass containers } \\
\qquad(125 \mathrm{~mL})\end{array}$ & $\begin{array}{c}5 \\
\text { to } \\
8\end{array}$ & - & Static & $4-10^{*}$ & Villamar, 1990 \\
\hline $\begin{array}{l}\mathrm{Cd} \\
\mathrm{Hg} \\
\mathrm{Pb}\end{array}$ & 10 & $\begin{array}{l}\text { Postlarvae } \\
\text { (PL 12) }\end{array}$ & Yes & Yes & $\begin{array}{l}\text { Beaker } \\
(600 \mathrm{~mL})\end{array}$ & - & 3 & $\begin{array}{c}\text { SR } \\
(24 h)\end{array}$ & $\begin{array}{l}2.49^{*} \\
1.23^{*} \\
134^{*}\end{array}$ & $\begin{array}{c}\text { Frías-Espericueta, } \\
\text { Voltolina \& } \\
\text { Osuna-López, } \\
2001\end{array}$ \\
\hline $\begin{array}{l}\mathrm{Cu} \\
\mathrm{Zn} \\
\mathrm{Mn}\end{array}$ & 10 & $\begin{array}{l}\text { Postlarvae } \\
\text { (PL 12) }\end{array}$ & - & Yes & $\begin{array}{l}\text { Beaker } \\
(600 \mathrm{~mL})\end{array}$ & - & - & $\begin{array}{c}\text { SR } \\
(24 h)\end{array}$ & $\begin{array}{c}- \\
2.08^{*} \\
130^{*}\end{array}$ & $\begin{array}{c}\text { Frías-Espericueta, } \\
\text { Voltolina \& } \\
\text { Osuna-López, } \\
2003\end{array}$ \\
\hline $\begin{array}{l}C d \\
Z n\end{array}$ & 10 & Postlarvae & - & - & $\begin{array}{l}\text { Beaker } \\
(1 \mathrm{~L})\end{array}$ & $\begin{array}{l}7 \\
5\end{array}$ & 3 & $\begin{array}{c}\text { SR } \\
(24 \mathrm{~h})\end{array}$ & $\begin{array}{l}1.07^{*} \\
1.35^{*}\end{array}$ & $\begin{array}{c}\text { Wu \& Chen, } \\
2004\end{array}$ \\
\hline Methamidophos & 10 & Juvenile & - & Yes & $\begin{array}{l}\text { Aquariums } \\
(7 \mathrm{~L})\end{array}$ & 6 & - & - & $1.46^{*}$ & $\begin{array}{l}\text { García-de la } \\
\text { Parra et al., } \\
2006\end{array}$ \\
\hline $\mathrm{Cu}$ & - & Juvenile & - & Yes & - & 5 & - & $\begin{array}{c}\text { SR } \\
(24 h)\end{array}$ & $35.12^{*}$ & $\begin{array}{c}\text { Frías-Espericueta } \\
\text { et al., } 2008\end{array}$ \\
\hline $\begin{array}{l}B(20 \%) \\
B(3 \% \circ)\end{array}$ & 20 & Juvenile & Yes & - & - & 6 & 3 & $\begin{array}{c}\text { SR } \\
(24 h)\end{array}$ & $\begin{array}{l}80.06^{*} \\
25.05^{*}\end{array}$ & Li et al.,2008 \\
\hline
\end{tabular}

*The original values are expressed in $\mathrm{mg} / \mathrm{L}$.

SR: static renewal.

\section{Organisms Supply and Maintenance}

L. vannamei postlarvae $20 \mathrm{~d}$ (PL10) to $30 \mathrm{~d}$ (PL15) were supplied by the Centro de Investigación de la Acuicultura en Colombia (CENIACUA) located in Punta Canoa, near Cartagena. Transportation was carried by land in special plastic bags with $20 \mathrm{~L}$ of marine water with oxygen saturation and controlled temperature and salinity conditions. Once in the laboratory, organisms were placed in $50 \mathrm{~L}$ aquarium with seawater salinity between 33 and 37, constant aeration, $12 \mathrm{~h}$ light $-12 \mathrm{~h}$ dark photoperiod, $30 \%$ daily water renewal and food supply (PL-400 25\%, 50\% Nicovita and 25\% pulverized Artemia) three times a day. Before their use for toxicity assays, organisms were in a period of acclimation between four to seven days. Considerations for their use were those established by the United States Environmental Protection Agency (EPA), which indicate that mortality during acclimation period cannot be more of $10 \%$ (EPA, 2002).

\section{Drilling Mud Preparation}

Muds were prepared at the Oceanography and Chemical Laboratory of the Universidad Jorge Tadeo Lozano de Bogotá, Santa Marta, by staff from the companies providing the muds, guaranteeing that preparation is similar to the one performed for drilling use. Samples were identified as E1, E2 and E3 (Companies) with the added letter $\mathrm{W}$ to refer WBM or the letter $\mathrm{S}$ in case of SBM. Conditions for mud storage and obtaining of Suspended Particulate Phase (SPP) for bioassays were based on Duke et al. (1984), Jones et al. (1986) and EPA (1993) recommendations.

The SPP was obtained previously by homogenizing the mud for 10 minutes with an electric mixer and then mixing one part of mud with nine parts of filtered seawater (Figure 1). Then, slurry was constantly mixed for $30 \mathrm{~min}$ and then allowed to settle for $1 \mathrm{~h}$. To separate the SPP, liquid slightly below 


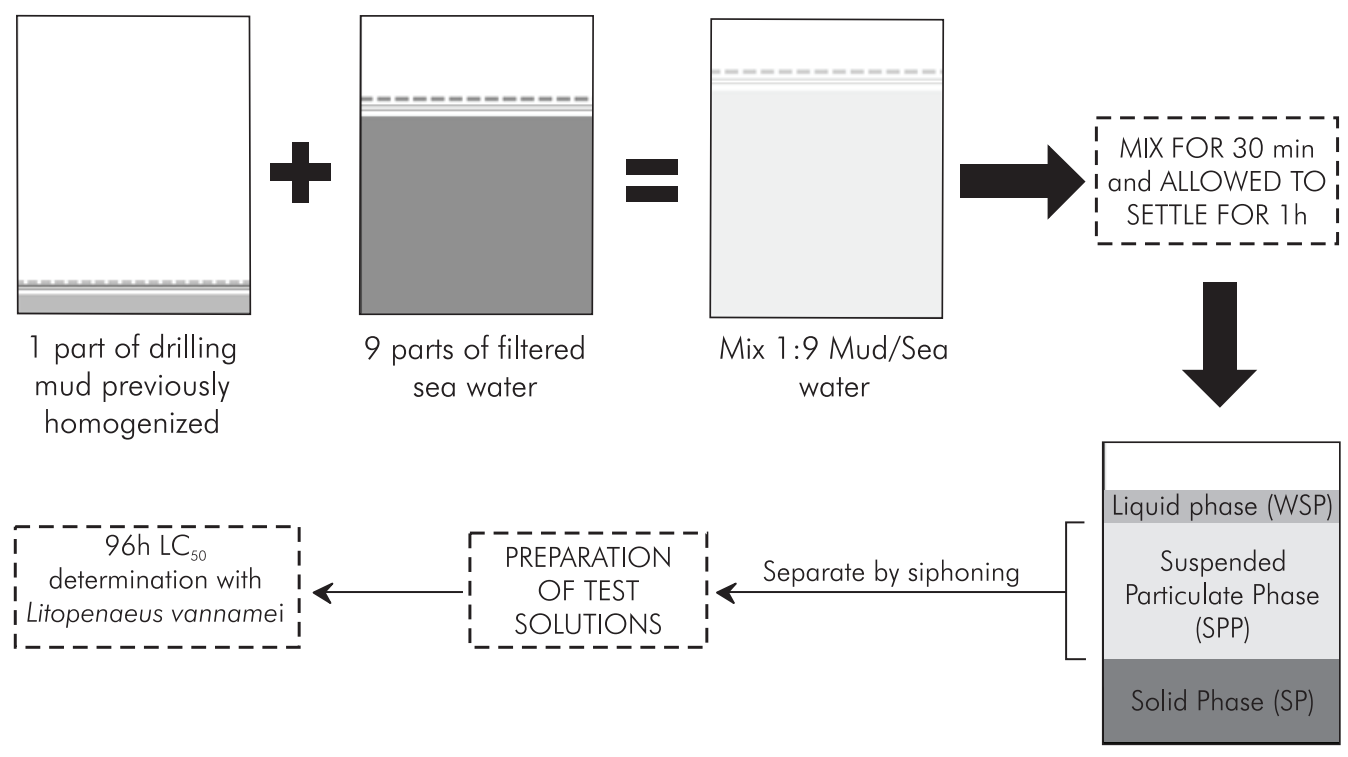

Figure 1. Suspended Particulate Phase (SPP) obtainment from drilling muds.

the surface and above the sediment or solid phase was siphoned and stored in a suitable container. This fluid represented the $100 \%$ SPP for the various test concentrations preparation.

\section{Acute Toxicity Tests}

Static renewal tests were performed to determine the $96 \mathrm{~h}$ median lethal concentration $\left(\mathrm{LC}_{50}\right)$. Range finding tests were conducted with serial decimal dilutions from $100 \%$ SPP to establish concentrations in the definitive tests; concentrations for definitive test were obtained mainly using a 0.5 factor from the minimum concentration where all organisms die in range finding test. During testing, five concentrations and a negative control with seawater were used, four replicates for each treatment and a total of 20 organisms placed randomly (five per replicate) in $1 \mathrm{~L}$ plastics containers with $500 \mathrm{ml}$ of test solution. Shrimps were fed two times a day and total renewal of solutions was done at $48 \mathrm{~h}$ (Table 2). Physicochemical parameters (PHC), were recorded $(\mathrm{pH}$, salinity, temperature and dissolved oxygen) at least in one of the replicates of each concentration and control at the beginning and end of test. Mortality was recorded every $24 \mathrm{~h}$, considering dead organisms those with lack of motility in the bottom of containers. As a test acceptability criterion, mortality in the control must not exceed $10 \%$.

Definitive testing concentrations used for each mud were: E1W (20000, 25000, 30000, 35000 and 40000 ppm), E2W (625, 1250, 2500, 5000 and 10000 ppm), E3W (6250, 12500, 25000, 50000 and $100000 \mathrm{ppm})$; E1S (6250, 12500, 25000, 50000 and $100000 \mathrm{ppm})$; E2S (5000, 10000, 50000, 100000 and $500000 \mathrm{ppm})$ and E3S (37500, 75000, 150000, 300000 and 400000 ppm).

Table 2. Experimental conditions for the acute test with L. vannamei.

\begin{tabular}{|c|c|}
\hline Test type & Static \\
\hline Time of exposure & $96 \mathrm{~h}$ \\
\hline Food supply & Twice daily \\
\hline Larval stage & Postlarvae (P| 10 - PI 15) \\
\hline Temperature & $25-27^{\circ} \mathrm{C}$ \\
\hline Salinity & $33-37$ \\
\hline Aireation & No \\
\hline Solution renewal & $48 \mathrm{~h}$ \\
\hline Dilution water & Filtered sea water \\
\hline Photoperiod & 12 h light / 12 h dark \\
\hline Test flasks & Plastic (1 L) \\
\hline Volume of sample test & $500 \mathrm{ml}$ \\
\hline Number of concentrations & 5 (plus control) \\
\hline Number of replicates & 4 \\
\hline Number of organisms per replicate & 5 \\
\hline Final meassured effect & Lethality; $\mathrm{LC}_{50} 96 \mathrm{~h}$ \\
\hline Test validation & Mortality in control $\leq 10 \%$ \\
\hline
\end{tabular}




\section{Statistical Analysis}

Median lethal concentrations (96h $\mathrm{LC}_{50}$ ) with $95 \%$ confidence interval were determined using free access software obtained from EPA (V. 1.5 Probit Analysis Program or Trimmed Spearman Karber).

\section{Control Chart}

Potassium dichromate $\left(\mathrm{K}_{2} \mathrm{Cr}_{2} \mathrm{O}_{7}\right)$ was used as reference toxicant. Control chart was generated in order to record the sensitivity, reproducibility and stability of the biological response of L.vannamei. Tests were performed under the same test conditions used with drilling muds to validate the protocol according to the criteria of the EPA (2002) and EPS (1990).

General process followed for acute toxicity assays of drilling muds with L. vannamei in the present study is shown in Figure 2.

\section{RESULTS AND DISCUSSION}

\section{Mortality}

During the first $48 \mathrm{~h}$, mortality for E1W and E3W were higher in the second highest concentration (35000 and $50000 \mathrm{ppm}$ respectively); after $48 \mathrm{~h}$ mortality of organisms increased due to the effects caused by drilling muds. The highest mortaly at $96 \mathrm{~h}$ for evaluated muds were found in the higher concentrations and mortality found in controls did not exceed 10\% (Table 3).

Mortalities for SBM were always higher at high concentrations during the time of test (100000, 500000 and $400000 \mathrm{ppm})$. E2S show no mortality at concentrations of 5000 and $10000 \mathrm{ppm}$, while E1S control presented $10 \%$ mortality (Table 4 ).

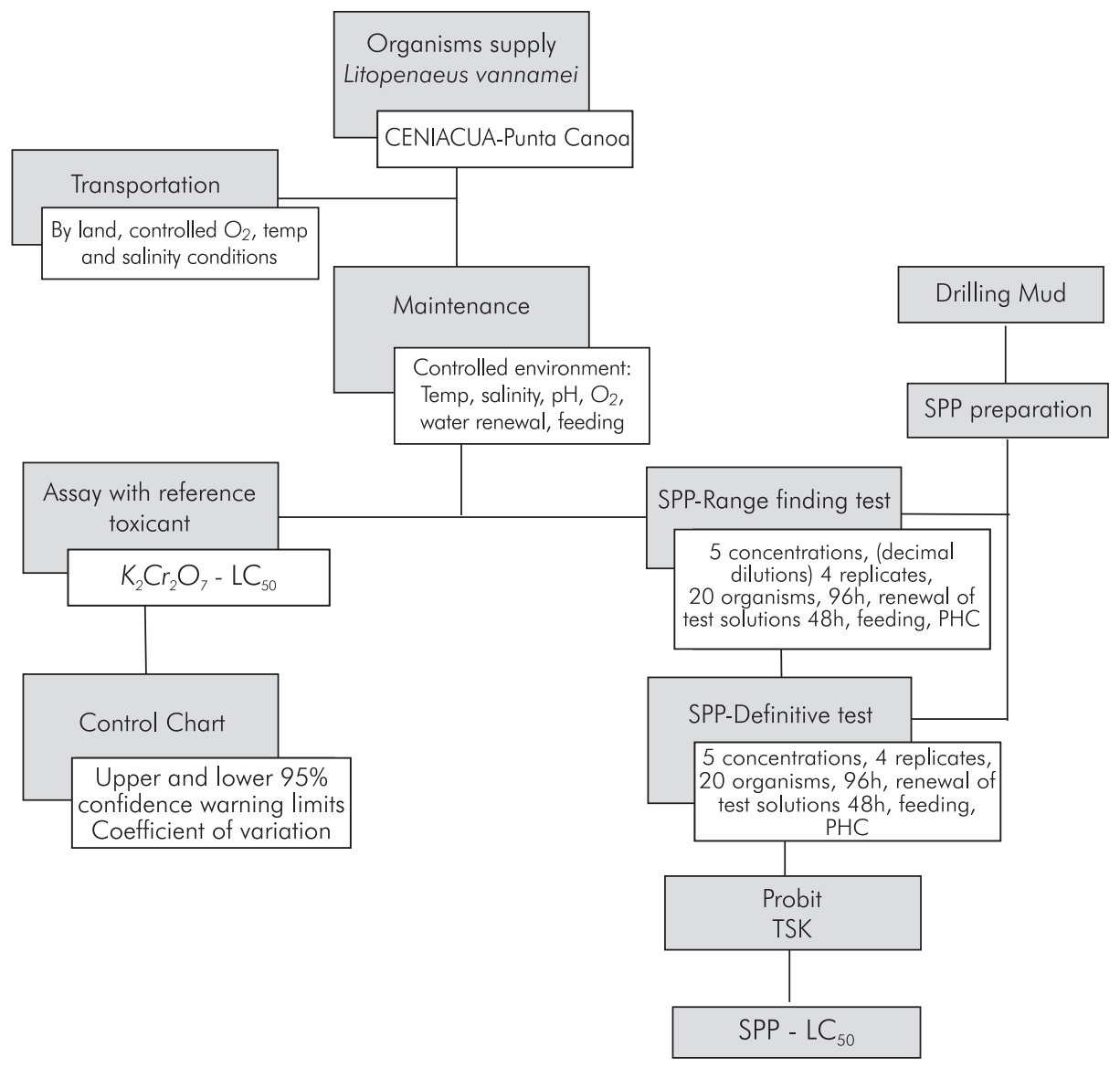

Figure 2. General procedure for an acute toxicity test of drilling mud with L. vannamei postlarvae. 


\section{Median Lethal Concentration}

$96 \mathrm{~h}$ acute toxicity values of drilling muds for $L$. vannamei with a $95 \%$ confidence interval are reported
(Table 5). For WBM, lower $\mathrm{LC}_{50}$ was 4224 (E2W) and the highest was $26635 \mathrm{ppm}$ in $\mathrm{E} 3 \mathrm{~W}$.

Table 3. Percentage mortality of L. vannamei exposed to water based drilling muds.

\begin{tabular}{|c|c|c|c|c|c|c|c|c|c|c|c|c|c|c|c|c|c|c|}
\hline \multirow[b]{2}{*}{$\begin{array}{l}\text { Time of } \\
\text { exposure } \\
\text { (h) }\end{array}$} & \multicolumn{6}{|c|}{ E1W } & \multicolumn{6}{|c|}{$\begin{array}{c}\text { E2W } \\
\text { SPP (ppm) }\end{array}$} & \multicolumn{6}{|c|}{ E3W } \\
\hline & 0 & \begin{tabular}{l}
8 \\
8 \\
0 \\
\hdashline
\end{tabular} & $\begin{array}{l}8 \\
8 \\
\text { ก }\end{array}$ & $\begin{array}{l}8 \\
8 \\
\text { ㅇ }\end{array}$ & $\begin{array}{l}8 \\
8 \\
\text { กิ }\end{array}$ & $\begin{array}{l}8 \\
8 \\
8\end{array}$ & 0 & గి & $\begin{array}{l}0 \\
\text { N } \\
-\end{array}$ & $\begin{array}{l}8 \\
8 \\
\text { N }\end{array}$ & $\begin{array}{l}8 \\
8 \\
n\end{array}$ & $\begin{array}{l}8 \\
8 \\
0\end{array}$ & 0 & $\begin{array}{l}\text { 유 } \\
\text { O }\end{array}$ & $\begin{array}{l}8 \\
\text { n } \\
N \\
N\end{array}$ & $\begin{array}{l}8 \\
8 \\
\text { n }\end{array}$ & $\begin{array}{l}8 \\
8 \\
0 \\
\text { ㅇ }\end{array}$ & $\begin{array}{l}8 \\
8 \\
8 \\
8\end{array}$ \\
\hline 24 & 0 & 20 & 30 & 5 & 45 & 25 & 0 & 0 & 0 & 0 & 0 & 0 & 0 & 0 & 0 & 30 & 45 & 35 \\
\hline 48 & 0 & 20 & 30 & 15 & 45 & 40 & 0 & 0 & 0 & 0 & 15 & 40 & 0 & 0 & 0 & 30 & 45 & 35 \\
\hline 72 & 0 & 45 & 40 & 50 & 75 & 85 & 10 & 5 & 25 & 30 & 55 & 90 & 5 & 0 & 0 & 50 & 90 & 95 \\
\hline 96 & 0 & 45 & 40 & 55 & 75 & 85 & 10 & 5 & 25 & 30 & 55 & 90 & 5 & 0 & 0 & 50 & 90 & 95 \\
\hline
\end{tabular}

SPP: solid particulate phase from drilling mud

Table 4. Percentage mortality of L. vannamei exposed to synthetic based drilling muds.

\begin{tabular}{|c|c|c|c|c|c|c|c|c|c|c|c|c|c|c|c|c|c|c|}
\hline \multirow[b]{2}{*}{$\begin{array}{l}\text { Time of } \\
\text { exposure } \\
\text { (h) }\end{array}$} & \multicolumn{6}{|c|}{ E1S } & \multicolumn{6}{|c|}{$\begin{array}{l}\text { E2S } \\
\text { SPP (ppm) }\end{array}$} & \multicolumn{6}{|c|}{ E3S } \\
\hline & 0 & ก & $\begin{array}{l}8 \\
\text { ㅇ } \\
\text { N }\end{array}$ & $\begin{array}{l}8 \\
8 \\
\text { ñ }\end{array}$ & $\begin{array}{l}8 \\
8 \\
0 \\
ㅇ ㅛ ~\end{array}$ & $\begin{array}{l}8 \\
8 \\
8 \\
0\end{array}$ & 0 & $\begin{array}{l}8 \\
8 \\
n\end{array}$ & $\begin{array}{l}8 \\
8 \\
0\end{array}$ & $\begin{array}{l}8 \\
8 \\
0 \\
\circ\end{array}$ & $\begin{array}{l}8 \\
8 \\
8 \\
\end{array}$ & $\begin{array}{l}8 \\
8 \\
8\end{array}$ & 0 & $\begin{array}{l}8 \\
\text { n̊ }\end{array}$ & $\begin{array}{l}8 \\
8 \\
1\end{array}$ & $\begin{array}{l}8 \\
8 \\
0 \\
1\end{array}$ & $\begin{array}{l}8 \\
8 \\
8 \\
8\end{array}$ & $\begin{array}{l}8 \\
8 \\
8 \\
8\end{array}$ \\
\hline 24 & 5 & 10 & 0 & 5 & 0 & 20 & 0 & 0 & 0 & 0 & 0 & 45 & 0 & 0 & 0 & 5 & 10 & 30 \\
\hline 48 & 10 & 10 & 0 & 5 & 0 & 20 & 0 & 0 & 0 & 0 & 0 & 45 & 0 & 0 & 5 & 5 & 25 & 30 \\
\hline 72 & 10 & 10 & 5 & 10 & 40 & 95 & 0 & 0 & 0 & 25 & 10 & 65 & 0 & 0 & 5 & 5 & 40 & 45 \\
\hline 96 & 10 & 10 & 5 & 20 & 70 & 100 & 0 & 0 & 0 & 25 & 10 & 65 & 0 & 0 & 5 & 40 & 45 & 55 \\
\hline
\end{tabular}

SPP: solid particulate phase from drilling mud

Table 5. Median letal concentration (with 95\% confidence limits) in L. vannamei.

\begin{tabular}{|c|c|c|c|c|c|c|}
\hline & \multicolumn{3}{|c|}{ Water based drilling muds } & \multicolumn{3}{|c|}{ Synthetic based drilling muds } \\
\hline & E1W & E2W & E3W & E1S & E2S & E3S \\
\hline $\mathrm{LC}_{50} 96 \mathrm{~h}$ & 24841 & 4224 & $26635^{*}$ & 40781 & 301813 & 308249 \\
\hline Lower limit & 18027 & 2542 & 21712 & 30058 & 175484 & 226503 \\
\hline Upper limit & 28799 & 6045 & 32674 & 50073 & 766085 & 510325 \\
\hline
\end{tabular}

*Calculated with Trimmed Spearman Karber analisys, all others with Probit analisys. 
The lowest $\mathrm{LC}_{50}$ found in $\mathrm{SBM}$ was $40781 \mathrm{ppm}$ for E1S and the highest was $308248 \mathrm{ppm}$ for E3S. Synthetic muds analyzed reached the highest toxicity values above $40000 \mathrm{ppm}$ of the SPP. The $96 \mathrm{~h} \mathrm{LC}_{50}$ for WBM ranged between 4224 to $26635 \mathrm{ppm}$ of the SPP. These results are within the range reported by other authors who have evaluated the toxicity of drilling muds with different species of marine organisms. In 1983, the report of the National Research Council found that almost $80 \%$ of the $\mathrm{LC}_{50}$ values of 400 muds assays with 62 species of marine organisms were above 10000 ppm (NRC, 1983; Neff, 2005). Evaluating the SPP of drilling muds Duke et al, (1984), determined the toxicity of eight generic drilling fluids with $M y$ sidopsis bahia, finding $\mathrm{LC}_{50}$ in the range of 27000 to $>1000000 \mathrm{ppm}$, being the lowest for the mud type KLC polymer. Duke and Parrish (1985), reported the results of an evaluation program of 11 drilling muds used in the Gulf of México finding a range of toxicity to mysids between 726 and $50000 \mathrm{ppm}$. The same muds were analyzed with shrimp Paleomonetes pugio and the range found was between 142 to $>100000 \mathrm{ppm}$ of whole mud. To a KLC-Polymer mud, Viega et al. (2001) reported an $\mathrm{LC}_{50}$ of $26400 \mathrm{ppm}$ with Brazilian species Mysidopsis juniae. In Indonesia, five active drilling muds were evaluated with Penaeus monodon, $\mathrm{LC}_{50}$ values ranged from 30740 to $78271 \mathrm{ppm}$ (Soegianto, Irawan \& Affandi, 2008).

All drilling muds were considered nontoxic (Table 6), according to the acute aquatic toxicity classification of the Joint Group of Experts on the Scientific Aspects of Marine Environmental Protection(GESAMP, 2002).

Table 6. Revised classification for acute aquatic toxicity from GESAMP (2002).

\begin{tabular}{|ccc|}
\hline Classification & Description & LC $_{50}$ (ppm) \\
\hline 0 & No toxic & $>1000$ \\
\hline 1 & Practically non toxic & $>100-\leq 1000$ \\
\hline 2 & Slightly toxic & $>10-\leq 100$ \\
\hline 3 & Moderately toxic & $>1-\leq 10$ \\
\hline 4 & Highly Toxic & $>0.1-\leq 1$ \\
\hline 5 & Very highly toxic & $>0.01-\leq 0.1$ \\
\hline 6 & Extremely toxic & $\leq 0.01$ \\
\hline
\end{tabular}

According to EPA (2002), is the responsibility of the laboratory to demonstrate its ability to obtain accurate and consistent results with a reference toxicant to validate a method that will be used for regulatory purposes. This intralaboratory precision is expressed as the coefficient of variation (CV\%) and should be determined by performing five or more tests with different groups of organisms under the same test conditions and data analysis, setting a $\mathrm{CV} \%$ of $\leq 30 \%$ as the maximum allowable variability when there are no standards references (EPS, 1990; Silva, Torrejon, Bay-Shmith \& Larrain, 2003). In the same way, a control chart should be prepared with at least 5 successive values of the reference toxicant to plot the average of all values and the upper and lower $95 \%$ confidence warming limits in a graphic. If two or more consecutive values fall outside the limits or seven consecutive results fall on the same side of the midline, procedures should be reviewed and should not be done any test until the proceedings are revalidated (EPA, 2002; ABNT, 2005). In the present study, we constructed the control chart with the reference toxicant, making 12 assays in parallel with drilling muds tests. The sensitivity of $L$. vannamei to $\mathrm{K}_{2} \mathrm{Cr}_{2} \mathrm{O}_{7}$ was determined and a $96 \mathrm{~h} \mathrm{LC}_{50}$ average of $33.80( \pm 3.51) \mathrm{ppm}$ was obtained (Figure 3), setting a sensitivity range at $95 \%$ represented by the lower limit of 26.78 and upper limit of $40.81 \mathrm{ppm}$. The coefficient of variation obtained was $10.38 \%$, so the accuracy achieved was superior to the suggested (EPS, 1990).

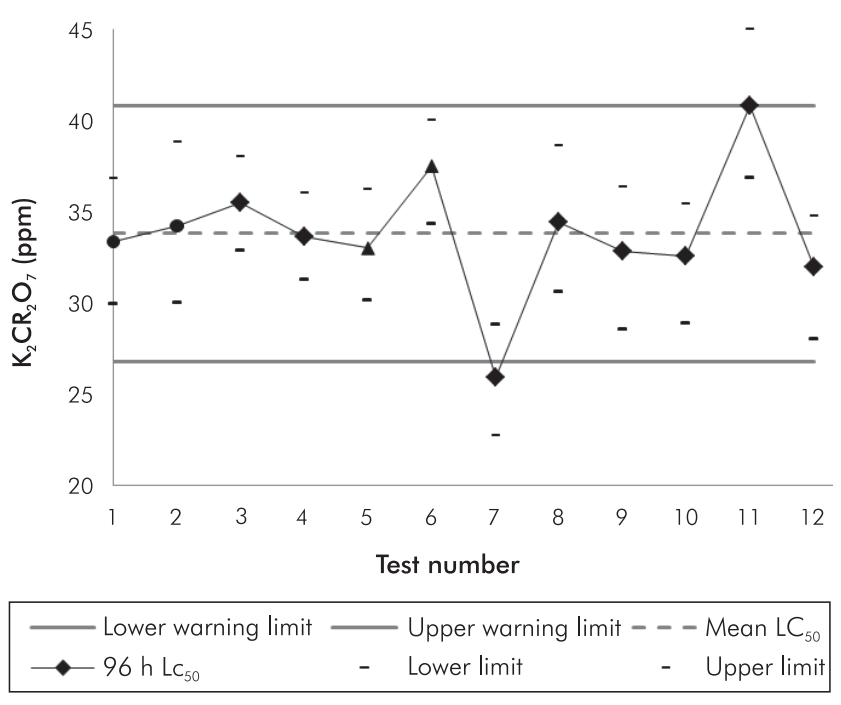

Figure 3. Control chart $96 \mathrm{~h}$ acute test with potassium dichromate for L. vannamei. 


\section{CONCLUSIONS}

- A protocol for acute toxicity evaluation generated during this research was successfully validated through a control chart using $\mathrm{K}_{2} \mathrm{Cr}_{2} \mathrm{O}_{7}$ as reference toxicant. Precision and accuracy of the results showed the correct application of the methodology and stability in the sensibility of L. vannamei.

- All drilling muds were considered as non-toxic according to GESAMP classification for acute aquatic toxicity established for chemicals substances.

- L. vannamei meets the requirements to be used in acute toxicity tests since it is obtained from a continuous production laboratory, is easily maintained under laboratory conditions and has been used worldwide.

- In order to take part in the regulation of drilling fluids discharges in the marine environment, toxicity studies in the country must continue. It is important to extend the range of native species to work with in terms of lethal and sub lethal effects (e.g. reproduction, growth, physiological response and DNA damage). Since lethal effects showed that drilling muds are not acutely toxic, sublethal effects in lower concentrations of $\mathrm{LC}_{50}$ should be evaluated in the future.

\section{ACKNOWLEDGEMENTS}

This research was conducted within the framework of the agreement for Technological Cooperation No. 007 of 2009 signed between ICP-Ecopetrol and Universidad Jorge Tadeo Lozano in the project "Evaluation of the toxicity of water and synthetic based drilling muds on Litopenaeus vannamei, Artemia salina and Argopecten nucleus in the development of toxicity tests of active components of drilling muds in marine invertebrates", conducted by research group: Dinámica y Manejo de Ecosistemas Marino-Costeros (DIMARCO).
The authors thank the Colombian Petroleum Institute (ICP) - Ecopetrol and the Faculty of Natural Sciences and Engineering of the University Jorge Tadeo Lozano - Santa Marta - for project funding and logistical support. To Dr. Carlos Andrés Suárez on behalf of CENIACUA, for support in providing L. vannamei post larvae and Dr. Arthur Leuterman for sharing his experience with us.

\section{REFERENCES}

ABNT. (2005). Ecotoxicologia aquática, toxicida de aguda, metodo de ensaio com misidaceos (Crustacea). NBR 15308. Asociacao Brasileira de Normas Técnicas. Brasil.

Campos, N., Navas, G., Bermúdez, A. \& Cruz, N. (2005). Los crustáceos decápodos de la franja superior del talud continental (300-500 m) del Mar Caribe colombiano. Bogotá: Universidad Nacional de Colombia. Facultad de Ciencias Naturales.

Code of Federal Regulations (2012). Oil and gas extraction point source category. Off shore sub category. Effluent limitations guidelines representing the degree of effluent reduction attainable by the application of the best available technology economically achievable (BAT). 40CFR435.13.

Cupello, A. C., Marroquín, A. C., Franca, J. \& Rabke, S. P. (2010). Comparison between acute and chronic toxicities of drilling fluids in Brazil: Is it possible to determine a correlation between them?. SPE International Conference on Health, Safety and Environment in Oil and Gas Exploration and Production, Rio de Janeiro, Brazil.

Duke, T. W. \& Parrish, P. R. (1985). Toxicity tests and Best Available Technology (BAT) determinations for discharge from offshore oil and gas platforms. United States Environmental Agency. Office of Water Regulations and Standards. Industrial Technology Division. 8th Annual Analytical Symposium. Norfolk, Virginia, USA.

Duke, T. W., Parrish, P. R., Montgomery, R. M., Macauley, S. D., Macauley, J. M. \& Cripe, G. M. (1984). Acute toxicity of eight laboratory-prepared generic drilling fluids to mysids (Mysidopsis bahia). EPA-600/3-84-067. 
EPA (1993). Oil and gas extraction point source category off shore subcategory. Effluent limitations guidelines and new source performance standards. 40CFR 435 .

EPA (2002). Methods for measuring the acute toxicity of effluents and receiving waters to freshwater and marine organisms. EPA -821-R-02-012.

EPS (1990). Guidance document on control of toxicity test precision using reference toxicants. Environment Canada. Report EPS 1/RM/12.

Fink, J. (2011). Petroleum engineer's guide to oil field chemicals and fluids. Chapter: Drilling muds. Waltham: Gulf Professional Publishing.

Frías-Espericueta, M. G., Voltolina, D. \& Osuna-López, J. I. (2001). Acute toxicity effects of cadmium, mercury, and lead to whiteleg shrimp (Litopenaeus vannamei) postlarvae. Bull. Environ. Contam. Toxicol., 67(4), 580-586.

Frías-Espericueta, M. G., Voltolina, D. \& Osuna-López, J. I. (2003). Acute toxicity of copper, zinc, iron, and manganese and of the mixtures copper-zinc and iron-manganese to whiteleg shrimp Litopenaeus vannamei postlarvae. Bull. Environ. Contam. Toxicol., 71(1), 68-74.

Frías-Espericueta, M. G., Castro-Longoria, R., BarónGallardo, G. J., Osuna-López, I., Abad-Rosales, S. M., Páez-Osuna, F. \& Voltolina, D. (2008). Histological changes and survival of Litopenaeus vannamei juveniles with different copper concentrations. Aquaculture, 278(1-4), 97-100.

García-de la Parra, L. M., Bautista-Covarrubias, J. C., Rivera-de la Rosa, N., Betancourt-Lozano, M. \& Guilhermino, L. (2006). Effects of methamidophos on acetylcholinesterase activity, behavior, and feeding rate of the white shrimp (Litopenaeus vannamei). Ecotox. Environ. Saf., 65(3), 372-380.

GESAMP (2002). The revised GESAMP hazard evaluation procedure for chemical substances carried by ships. Reports and Studies, Joint Group of Experts on the Scientific Aspects of Marine Environmental Protection (GESAMP) No. 64.

Jones, F. V., Moffitt, C. M., Bettge, W., Leuterman, A. J. J. \& Garrison, R. (1986). Drilling fluids firms respond to EPA toxicity concerns. Oil Gas J., 84: 71-77.
Li, E., Xiong, Z., Chen, L., Zeng, C. \& Li, K. (2008).Acute toxicity of boron to juvenile white shrimp, Litopenaeus vannamei, at two salinities. Aquaculture, 278(1-4), $175-178$.

Luvesuto, E., Domingues de Freitas, P. \& Galleti, P. M. (2007). Genetic variation in a closed line of the white shrimp Litopenaeus vannamei (Penaeidae). Genet. Mol. Biol, 30(4), 1156-1160.

Melton, H. R., Smith, J. P., Martin, C. R., Nedwed, T. J., Mairs, H. L. \& Raught, D. L. (2000). Offshore discharge of drilling fluids and cuttings a scientific perspective on public policy. Rio Oil \& Gas Expo and Conference. Rio de Janeiro. Brazil. IBP 44900.

National Research Council. (1983). Drilling discharges in the marine environment. Washington. D.C.: National Academy Press.

Neff, J. M. (2005). Composition, environmental fates, and biological effects of water based drilling muds and cuttings discharged to the marine environment: A Synthesis and annotated bibliography. Reported prepared for Petroleum Environmental Research Forum (PERF) and American Petroleum Institute. Washington D.C.

Neff, J. M. (2008). Estimation of bioavailability of metals from drilling mud barite. Integr. Environ. Assess. Manag., 4(2), 184-193.

Rivera-Velásquez, G., Salgado-Ugarte, I., Soto, L. \& Naranjo, E. (2010). Un estudio de caso en el análisis de la distribución de frecuencias de tallas de Litopenaeus vannamei (Boone, 1931) mediante el uso de estimadores de densidad de Kernel. Lat. Am. J. Aquat. Res., 38(2), 201-209.

Silva, J., Torrejón, G., Bay-Schmith, E. \& Larrain, A. (2003). Calibración del bioensayo de toxicidad aguda con Daphnia pulex (Crustácea: Cladócera) usando un toxico de referencia. Gayana, 67(1), 87-96.

SIPA. (2009). Pesca de camarón en el Caribe Colombiano. Sistema de información de pesca y acuacultura. Boletín mensual, 40: 1-18.

Soegianto, A., Irawan, B. \& Affandi, M. (2008). Toxicity of drilling waste and its impact on gill structure of post larvae of tiger prawn (Penaeus monodon). Glob. J. Environ. Res. 2(1), 36-41. 
Valles-Jiménez, R., Cruz, P. \& Pérez-Enríquez, R. (2005). Population genetic structure of Pacific White shrimp (Litopenaeus vannamei) from Mexico to Panama: microsatellite DNA variation. Mar. Biotechnol, 6(5), 475-484.

Veiga, L. F., Tostes, Z. T., Reynier, M. V., Brandão, G. F., R. \& Oliveira, F. F. (2001). Marine toxicity of drilling fluids. SETAC $22^{\text {nd }}$ Annual Meeting. Baltimore, Maryland, USA. PH 002.

Villamar, F. (1990). Bioensayo para calcular el $\mathrm{CL}_{50}$ del dispersante de petróleo BP 1100-WD con larvas de camarón Penaeus vannamei. Acta Oceanográfica del Pacífico, 6(1), 73-78.

Wu, J. P. \& Chen, H. C. (2004). Effects of cadmium and zinc on oxygen consumption ammonium excretion, and osmoregulation of white shrimp (Litopenaeus vannamei). Chemosphere, 57(11), 1591-1598.

\section{AUTHORS}

\section{Guillermo-José Contreras-León}

Affiliation: Universidad de Bogotá Jorge Tadeo Lozano. Biologist, Universidad Nacional Mayor de San Marcos. Spe. in Microbioloy and Parasitology, Universidad Nacional Mayor de San Marcos.

e-mail: gcontreras777@yahoo.com

\section{Simón-Andrés Rodríguez-Satizábal}

Affiliation: Universidad de Bogotá Jorge Tadeo Lozano. Marine Biologist, Universidad de Bogotá Jorge Tadeo Lozano. M. Sc. (Candidate) in Marine Science, Universidad de Bogotá Jorge Tadeo Lozano.

e-mail: simon.rodriguezs@utadeo.edu.co

\section{Claudia-Marcela Castellanos-Romero}

Affiliation: Universidad de Bogotá Jorge Tadeo Lozano. Marine Biologist, Universidad de Bogotá Jorge Tadeo Lozano. Spe. in Environmental Education, Universidad Santo Tomás de Aquino.

M. Sc. in Marine Biology, Universidad Nacional de Colombia. e-mail: claudiacastellanos05@yahoo.com

\section{Andrés Franco-Herrera}

Affiliation: Universidad de Bogotá Jorge Tadeo Lozano. Marine Biologist, Universidad de Bogotá Jorge Tadeo Lozano. $\mathrm{Ph}$. D. Oceanography, Universidad de Concepción. e-mail: afrancohz@gmail.com

\section{Marlon Serrano-Gómez}

Affiliation: Ecopetrol S.A. - Instituto Colombiano del Petróleo. Biologist, Pontificia Universidad Javeriana. Spe. in Environmental Chemistry, Universidad Industrial de Santander. e-mail: marlon.serrano@ecopetrol.com.co 
